\title{
妊婦の経時的姿勢，運動変化が腰部に与える影響
}

\section{The Effect of Change in Posture and Movement during Pregnancy on the Lower Back}

\author{
武田＼cjkstart要1）＼cjkstart勝平 純司2)＼cjkstart藤沢しげ子2) \\ KANAME TAKEDA ${ }^{1)}$, JYUNJI KATUHIRA ${ }^{2)}$, SHIGEKo FUJISAWA ${ }^{2)}$ \\ 1) Nihon Rehabilitation College: 3-6-18 Takada, Toshima-ku, Tokyo 171-0033, Japan. TEL +81 3-5954-6511 \\ 2) Department of Physical Therapy, Faculty of Health Science, International University of Health and Welfare
}

Rigakuryoho Kagaku 22(2): 281-285, 2007. Submitted Oct. 30, 2006. Accepted Jan. 23, 2007.

\begin{abstract}
The purpose of this study was to show the effect of change in posture and movement during pregnancy on the lower back using a three-dimensional motion analysis system. Three pregnant women participated in this study when they were in the sixth and eighth months of pregnancy. Trunk forward and backward moments during static standing and level walking were analyzed. The trunk forward and backward moments were in proportion to trunk bending angle in two subjects. However, the trunk forward and backward moments decreased in spite of the increase in trunk bending angle with pregnancy progress in one subject. These results suggest that center of gravity of HAT (head, arm, trunk) moved anteroinferior due to abdominal swelling in pregnancy resulting in shorter lever arm between joint centre and gravitational force. The trunk backward moment decreased in the second half of a double stance phase in walking because inertial force applied to centre of gravity in HAT and trunk angle affected trunk moment. However, one subject did not exert trunk backward moment in spite of increased trunk forward bending angle and backward component of floor reaction force. This was also due to center of gravity of HAT moving anteroinferior resulting in shorter lever arm.
\end{abstract}

Key words: pregnancy, three-dimensional motion analysis system, the trunk forward and backward moments

要旨: 本研究では妊婦期の姿勢, 運動の経時的変化が腰部へ及ぼす影響を知るために妊娠 24 週と32週での静止立位時 と歩行時の体幹前後屈モーメントを3次元動作解析装置にて計測した。立位では2例で体幹角度と体幹モーメントは比 例関係を示していたが，1例では妊娠経過と共に体幹後傾角度増加にもかかわらず体幹前屈モーメントは減少してい た。このことは妊娠経過に伴う腹部膨隆により生じる身体重心の前方移動によりHAT（頭部，両上肢, 体幹）の重心 が前下方へ移動し回転中心と重力とのレバーアームが短くなった為と考えた。歩行時ではHATの重心に生じる慣性力 と体幹角度が体幹前後屈モーメントに影響を与える為, 体幹後屈傾向の例では両脚支持期後半において体幹後屈モー メントが減少していた。一方で両脚支持期後半に体幹角度, 床反力後方成分の増加にかかわらず体幹後屈モーメント が発生しない被験者も存在し，HATの重心が下方に位置しレバーアームが短くなった為と考えられた。 キーワード：妊婦，3次元動作解析，体幹前後屈モーメント

1) 日本リハビリテーション専門学校：東京都豊島区高田3-6-18（テ171-0033）TEL03-5954-6511

2) 国際医療福祉大学 保健学部理学療法学科

\section{受付日 2006年10月30日受理日 2007年1月23日}




\section{I.はじめに}

妊婦の身体重心は妊娠経過に伴い腹壁が突出するこ とにより前方へ移動し, 過度な重心の前方移動を抑制す るために体幹を後傾させることが一般的な妊婦の姿勢 変化として知られている。このことは妊娠期の問題のひ とつである腰痛の要因になるといわれている $\left.{ }^{1}\right) 。$ 村井ら は腰痛を呈した妊婦の割合が $78.9 \%$ と高率を示したこと を報告しており，そのうちリラキシンホルモンによる骨 盤不安定症由来の仙腸関節痛についで姿勢変化由来の 腰背部痛が妊婦の訴えとして認められたと報告してい る2)。Ostgaardらは855名の妊婦の調查により, 矢状腹径, 横断腹径の大きさ, 腰椎前彎の深さが背部痛に関連する 要因であることを報告している3)。またDavids J.R.らは バイオメカニクスの面から15名の妊婦を対象に平地歩行 を分析し, 産後 1 年経過時と比べて妊娠後期に股関節伸 展, 外転, 足関節底屈モーメントが有意に増加していた と述べている4)。しかし妊娠による身体の経時的変化が 腰部へもたらす影響をバイオメカニクスの面から明ら かとした報告はない。よって本研究では健常妊婦 3 名を 対象に妊婦の安定期から妊娠後期の身体の経時的変化 が腰部負担に及ぼす影響を妊娠 24 週と 32 週での静止立位 時と歩行時における体幹前後屈モーメントを指標とし, 三次元動作解析装置と床反力計を用いた動作分析手法 により明らかにすることを目的とした。

\section{II. 対象と方法}

\section{1. 対象}

2005年7月から 2006 年3月の期間において, 個人情報の 守秘義務と研究の目的と方法を説明し, 承諾を得た上 で, 過去3个月において特記すべき既往のない健常妊婦 3 名（年齢： $23 \pm 1.53$ 歳, 身長 : $158.7 \pm 6.03 \mathrm{~cm}$, 非妊娠 時体重 $53 \pm 7.55 \mathrm{~kg}$ ) を対象とした。

2. 計測システム

測定には3次元動作解析システムVICON612（VICON 社製), 床反力計 (AMTI社製) 6枚, サンプリング周波 数 $120 \mathrm{~Hz}$ の赤外線カメラ 8 台を用いた。

3. マーカー位置と計測定義

マーカーは臨床歩行分析研究会の推奨する方法を参 考にし, 直径 $25 \mathrm{~mm}$ の赤外線反射マーカーを左右計 20 箇 所（第5中足骨指節間関節，腓骨外果，膝蓋骨中央の高 さで膝蓋骨の厚さを除く膝関節前後径の中点, 大転子,
上前腸骨棘，L5䊂突起，剣状突起，Th12䊂突起，C7束 突起，肩峰，左右耳垂直上，頭頂，ダミー）に貼付した。 下肢関節角度に関しては, 股関節角度は鉛直軸に対する 大腿の角度, 膝関節は大腿と下腿のなす角度, 足関節は 腓骨への垂直線を基本軸とする第3中足骨との角度で, それぞれ屈曲・背屈をプラスとし, 体幹前後傾角度は左 右肩峰の中点と左右股関節の中点を結んだ直線の鉛直 軸に対する傾きで示した ${ }^{5)}$ 。

\section{4. 体幹前後屈モーメントの定義}

動作中における妊婦の腰部モーメントを求めるため には, Cappozzoが先行研究で健常男性に用いているよう に第 4 , 第 5 腰椎間を回転中心として求める方法がより妥 当性の高い方法と考える6)。しかし，妊婦では胎児や腹 水を含んだ骨盤部の質量, 質量中心位置, 慣性モーメン 卜などを算出することが困難であり，この位置を腰部 モーメントの回転とした場合腰部モーメントを正確に 算出することができない。また妊婦では腹部が大きくな ることで骨盤と胸郭の分節的な運動が少なくなるため, 非妊婦よりも体幹を一つの剛体としてとらえやすくな る。以上のことから本研究では勝平が用いた体幹をひと つの剛体とみなし, 左右の股関節の中点を腰部の回転中 心として算出する体幹前後屈モーメントを腰部負担の 指標として用いた7)。体幹前後屈モーメントは左右股関 節中点を回転中心にした体幹の前後屈の際に頭部, 両上 肢，体幹（以下HATと記述する。）の重心にかかる重力 によるモーメントに拮抗するモーメントである。また体 幹前後屈モーメントの大きさは体幹前後屈角度の大き さに比例する。すなわち静止立位において前屈時には HATに生じる重力によるモーメントと同等の体幹後屈 モーメントが発生し体幹後面筋群の活動を示し, 後屈時 には同様に体幹前屈モーメントが発生し体幹前面筋群 の活動を示す（図1a）。歩行時においてはさらにHATの 重心にかかる慣性力が体幹前後屈モーメントの大きさ に影響を及ぼす。歩行時HATの重心に生じる慣性力は左 右股関節の中点に生じる前後方向の加速度と反対方向 に生じる（図1b）。そのため左右股関節の中点の近傍に 位置する身体重心に生じる前後方向の加速度と体幹前 後屈モーメントは比例する。体幹前後屈モーメントは左 右股関節の中点を回転中心とするため, 左右の股関節 モーメントを加算し極性を反転させたものとその值が 等しくなる。この体幹前後屈モーメントの算出には胎児 や腹水を含んだ骨盤部の質量, 質量中心位置, 慣性モー メントを必要としないため, 信頼性の高い計算結果を得 ることが可能となる。 


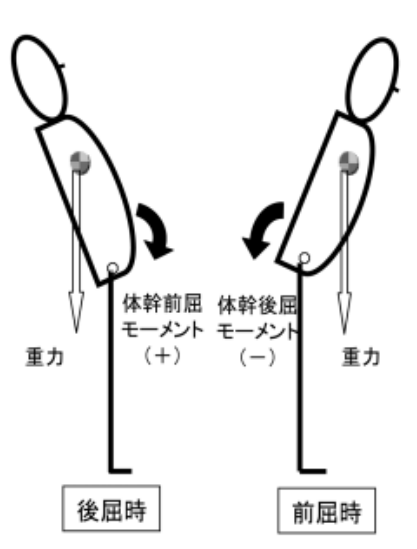

a. 静止立位時
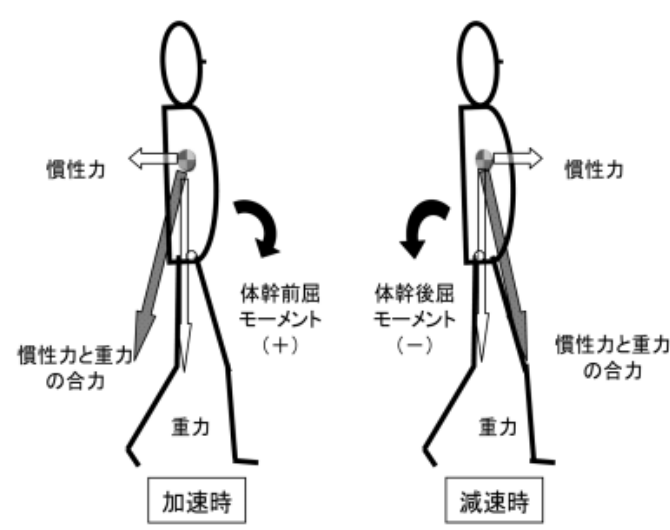

b. 歩行時

図1 体幹前後屈モーメントの定義

\section{5. 測定項目}

矢状面でのアライメントと体幹前後屈モーメントと の関係を把握するため静止立位時では体幹前後屈角度 を測定項目とした。歩行動作では体幹角度に加え体幹へ の慣性力に影響を与える身体重心の加速度を表す合成 床反力前後成分を解析パラメータとした。腰部への負担 を経時的にみるために体幹前後屈モーメントを計測し， 静止立位時では5秒間の平均值, 歩行時では1歩行周期で の最大，最小ピーク值を解析した。

\section{6. 測定課題}

測定課題は静止立位と平地歩行とした。静止立位を5 秒間計測した後, $5 \mathrm{~m}$ の平地歩行を 3 回行い速度は自由速 度とした。一定の姿勢を保つため進行方向の視線の高さ に目印をおき, 注視させる様にした。計測は妊娠安定期 である24週と32週の時期に行った。

\section{III. 結 果}

1. 体幹前後屈角度と体幹前後屈モーメントの経時的変化

1）静止立位時

各妊婦の 24 週と 32 週における体幹前後屈角度と体幹 前後屈モーメントの值を表1に示す。いずれの妊婦も体 幹は後傾し体幹前屈モーメントが発生していた。妊婦ご とに見ていくと妊婦Aでは経過と共に徐々に体幹が後傾 しているのにもかかわらず体幹前屈モーメントは減少 していた。妊婦Bでは経過と共に体幹が前傾していき 32 週の体幹前屈モーメントは24週のおよそ5分の1に減少し ていた。妊婦Cも妊婦B と同様に経過と共に体幹前傾し
表1 立位時の体幹角度と体幹前後屈モーメント

\begin{tabular}{cccc}
\hline & $\begin{array}{c}\text { 体幹角度 } \\
\text { 後屈 }+(\mathrm{deg})\end{array}$ & $\begin{array}{c}\text { 体幹前後屈モーメント } \\
\text { 前屈 }+(\mathrm{Nm})\end{array}$ \\
\hline $\mathrm{A}$ & 妊娠 24 週 & $6.38 \pm 0.23$ & 23.38 \\
& 妊娠 32 週 & $9.19 \pm 0.11$ & 21.95 \\
$\mathrm{~B}$ & 妊娠 24 週 & $7.49 \pm 0.13$ & 22.15 \\
& 妊娠 32 週 & $5.44 \pm 0.34$ & 4.52 \\
$\mathrm{C}$ & 妊娠 24 週 & $5.25 \pm 0.16$ & 6.01 \\
& 妊娠 32 週 & $3.65 \pm 0.10$ & 2.88 \\
\hline
\end{tabular}

体幹前屈モーメントの減少が見られていた。

2）歩行時

いずれの妊婦においても妊娠周期の違いによる歩行 速度の変化は見られなかった（24週 : $1.18 \pm 0.16 \mathrm{~m} / \mathrm{s}, 32$ 週: $1.23 \pm 0.13 \mathrm{~m} / \mathrm{s}$ )。1歩行周期における体幹前後屈モー メントの代表例を示す (図2)。いずれの妊婦においても 両脚支持期前半にて体幹前屈モーメントピーク值, 両脚 支持期後半では体幹後屈モーメントピーク值が確認で きた。また両脚支持期での体幹角度と床反力前後成分の 波形を見ると, 両脚支持期前半部では床反力前方成分は ピーク值, 体幹角度は最小值を示し, 両脚支持期後半に おいて床反力後方成分はピーク值, 体幹角度は最大值を 示していた。

次に体幹前後屈モーメント值, 体幹角度, 合成床反力 前後成分ピーク值平均值を, 両脚支持期前半, 後半に分 けて各妊婦で24週と32週との比較を行った（表2）。これ らより全ての妊婦において必ずしも妊娠経過と共に体 幹後屈角度, 体幹前後屈モーメントが増加していく傾向 


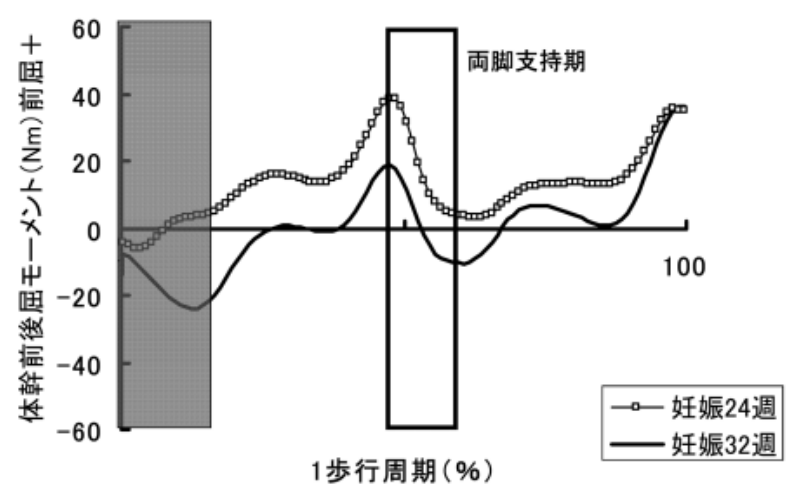

図2 妊婦歩行時体幹前後屈モーメント代表例

は見られなかった。次に妊婦 $\mathrm{A} ， \mathrm{~B} ， \mathrm{C}$ それ゙れにおける 体幹前後屈モーメントと床反力, 体幹角度を示す。

妊婦Aについて）両脚支持期前半について妊娠経過に 伴い床反力前方成分, 体幹後屈角度が増加し体幹前屈 モーメントは増加していた。両脚支持期後半では妊娠経 過に伴う床反力後方成分の増加, 体幹後屈角度にかかわ らず体幹前屈モーメントが発生していた。

妊婦Bについて）両脚支持期前半では経過と共に体幹 後屈角度は減少するのに対し体幹前屈モーメントは減 少していた。両脚支持期後半は体幹後屈角度減少と床反 力後方成分の増加が見られ体幹後屈モーメントは増加 していた。

妊婦Cについて）両脚支持期前後半とも妊婦 $\mathrm{B}$ 同様 の傾向を示していた。

\section{IV. 考 察}

1. 立位時の体幹前後屈モーメントの経時的変化の要素 立位での身体重心位置はおよそ第2仙骨前方にあると 言われ ${ }^{8)}$, 成人男性では $56 \%$, 成人女子では身長の $55 \%$ 程度の高さにあるとされている9)。また頭部, 両上肢, 上部体幹の重心であるHATは大転子から上腕関節を結 んだ線状の遠位から $0.678 \%$ の位置にあるとされ胸骨の 高さ付近にあると考えられる10)。一般的な妊婦の静止立 位姿勢は胎児が成長するにつれ，子宮拡大による腹部膨 隆がおこり身体重心は前方へ移動する11)。さらにいずれ の妊婦も24週と32週の体重変化を見るとおよそ2 kgの体 重増加を認めていたため胎児の成長と共にHATの重心 にかかる重力そのものも増加すると考えられる。このた め静止立位時では体幹前後屈モーメントは妊娠経過と ともに体幹が後屈してHATの重心に生じる重力とつり あいを保つために体幹前屈モーメントが増加すると予 想される。妊婦B，Cにおいては体幹角度変化と体幹前

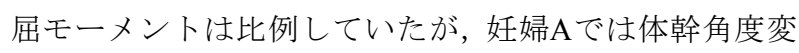
化と体幹前屈モーメントにおいて比例関係が見られな かった。このことは妊娠経過による腹部膨隆によりHAT の重心が前下方への移動していたためと考える。すなわ ち妊婦Aでは体幹後屈しているのにもかかわらずHATの 重心位置が妊娠経過のため本来のHATの位置より前下 方に位置し回転中心と重力とのレバーアームが短くなっ ていたため体幹前屈モーメントが減少していたと考え られた。

2. 歩行時の体幹前後屈モーメントの経時的変化の要素 動作時の体幹前後屈モーメントに与える因子として HATの重心に生じる慣性力と体幹角度がある。すなわち 両脚支持期前半において合成床反力前方成分と体幹後

両脚支持期での体幹前後屈モーメント, 合成床反力成分, 体幹角度

\begin{tabular}{|c|c|c|c|c|c|c|c|}
\hline & & \multicolumn{3}{|c|}{ 両脚支持期前半 } & \multicolumn{3}{|c|}{ 両脚支持期後半 } \\
\hline & & $\begin{array}{c}\text { 体幹前後屈モーメント } \\
\text { ピーク值 }(\mathrm{Nm})\end{array}$ & $\begin{array}{c}\text { 床反力前方成分 } \\
(\mathrm{N})\end{array}$ & $\begin{array}{c}\text { 体幹角度 } \\
(\mathrm{deg})\end{array}$ & $\begin{array}{c}\text { 体幹前後屈モーメント } \\
\text { ピーク值 }(\mathrm{Nm})\end{array}$ & $\begin{array}{c}\text { 床反力前方成分 } \\
(\mathrm{N})\end{array}$ & $\begin{array}{c}\text { 体幹角度 } \\
(\operatorname{deg})\end{array}$ \\
\hline & 妊娠 24 週 & 23.68 & 123.04 & 1.35 & -2.82 & -112.78 & 3.54 \\
\hline & 妊娠 32 週 & 39.30 & 138.35 & 5.36 & 11.81 & -130.29 & 7.65 \\
\hline \multirow{2}{*}{ B } & 妊娠 24 週 & 39.23 & 139.56 & 3.23 & -0.45 & -115.29 & 4.58 \\
\hline & 妊娠 32 週 & 21.82 & 156.97 & 0.39 & -11.12 & -135.50 & 2.38 \\
\hline \multirow[t]{2}{*}{$\mathrm{C}$} & 妊娠 24 週 & 15.47 & 89.47 & 0.18 & 1.50 & -88.24 & 2.83 \\
\hline & 妊娠 32 週 & 10.82 & 116.14 & -0.02 & -3.36 & -114.90 & 2.69 \\
\hline
\end{tabular}




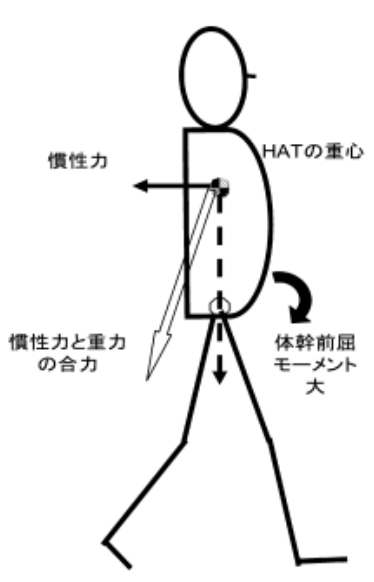

a. 非妊娠時

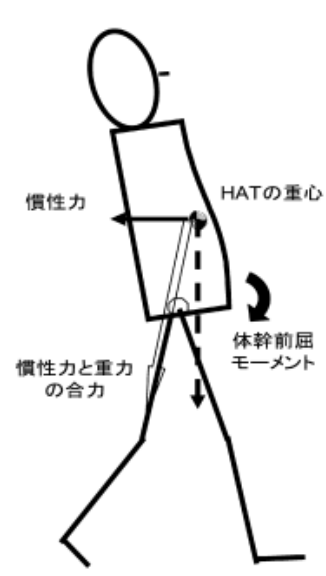

b. 妊娠時

図3 非妊娠時と妊娠時の体幹前後屈モーメント

屈角度が増加すれば, 慣性力とHATの重力の合成力と回 転中心とのレバーアームが長くなり体幹前屈モーメン 卜が増加する。両脚支持期後半では合成床反力後方成分 と体幹前屈角度が増加すれば反対に体幹後屈モーメン トが増加する。これらをそれぞれの妊婦経過に伴うHAT の重心位置移動を含め考察する。

妊婦Aについて）両脚支持期前半については体幹後屈 角度が増加することで前屈モーメントのレバーアーム が長くなる事が考えられる。さらに床反力前方成分と重 力の増加による慣性力と重力の合成力増加することで 体幹前屈モーメントが増加していたと考えられた。両脚 支持期後半での体幹後屈モーメントが減少したのは体 幹後屈角度が増加することで後屈モーメントのレバー アームが短くなったためと考えられた。

妊婦Bについて）両脚支持期前半での体幹前屈モーメ ントの減少は妊婦 $\mathrm{A}$ と逆に体幹後屈角度が減少するこ とにより前屈モーメントのレバーアームが短くなった 為と考える。両脚支持期後半での体幹後屈モーメントの 増加は床反力後方成分が増加したことと体幹後屈傾向 が減少することで後屈モーメントのレバーアームが長 くなったことが考えられた。

妊婦Cについて）妊婦B と同様の妊娠経過による体幹 後屈角度の減少のため体幹前後屈モーメントの変化も 妊婦B と同様の傾向を示していたものと考えられた。

これらより妊娠時の体幹前後屈モーメントは胎児の 発達, 位置によるHATの重心位置変化のため体幹角度に 大きく影響されることが考えられ, 体幹後面筋群の活動
を示す体幹後屈モーメントは妊婦B，Cのように体幹後 屈角度減少のケースで歩行時に見られていたことがわ かった。

\section{引用文献}

1) 高木 哲, 久本浩二, 金井利仁 : 妊婦と腰痛. 産婦人科治 療, 1996, 73(3): 277-279

2) 村井みどり, 楠見由里子, 椎名美博・他 : 妊婦および裖婦に おける腰痛の実態調查. 理学療法学, 2003, 30: 91.

3) Ostgaard HC, Andersson GB, Schultz AB, et al.: Influence of some biomechanical factors on low-back pain in pregnancy. Spine, 1993, 18: 61-65.

4) Foti $T$, Davids JR, Bagley A: A biomechanical analysis of gait during pregnancy. J Bone Joint Surg (Am), 2000, 82A(5): 625632.

5) 山本澄子, 江原義弘 : ボディダイナミクス入門 片麻痺者の 歩行と短下肢装具, 1版. 医歯薬出版, 東京, 2005, pp54-58.

6) Cappozzo A: The forces and couples in the human trunk during level walking. J Biomech, 1983, 16(4): 265-277.

7) 勝平純司, 山本澄子, 丸山仁司・他 : 階段およびスロープ昇 降時の腰部負担の比較. 日本義肢装具学会誌, 2004, 19(1), 5258.

8) Galley PM, Forster AL: Human movement, 2nd ed. Churchill Livingstone, Melbourne, 1989.

9) 中村隆一, 斉藤 宏: 基礎運動学 第4版. 医歯薬出版, 東 京, 1992, pp289-309.

10) Winter DA: Biomechanics and motor control of human movement third edition. John Wiley \& Sons Inc, New York, 2004, p64.

11) 理学療法科学学会 (監修) : ザ・歩行. アイペック, 東京, 2002, pp59-60. 